\title{
The LexA regulated genes of the Clostridium difficile
}

\author{
Beata M Walter ${ }^{1}$, Maja Rupnik ${ }^{1,2,3}$, Vesna Hodnik, Gregor Anderluh ${ }^{4,5}$, Bruno Dupuy $^{6}$, Nejc Paulic ${ }^{4}$, \\ Darja Žgur-Bertok ${ }^{4}$ and Matej Butala ${ }^{4^{*}}$
}

\begin{abstract}
Background: The SOS response including two main proteins LexA and RecA, maintains the integrity of bacterial genomes after DNA damage due to metabolic or environmental assaults. Additionally, derepression of LexA-regulated genes can result in mutations, genetic exchange and expression of virulence factors. Here we describe the first comprehensive description of the in silico LexA regulon in Clostridium difficile, an important human pathogen.
\end{abstract}

Results: We grouped thirty C. difficile strains from different ribotypes and toxinotypes into three clusters according to lexA gene/protein variability. We applied in silico analysis coupled to surface plasmon resonance spectroscopy (SPR) and determined 16 LexA binding sites in C. difficile. Our data indicate that strains within the cluster, as defined by LexA variability, harbour several specific LexA regulon genes. In addition to core SOS genes: lexA, recA, ruvCA and uvrBA, we identified a LexA binding site on the pathogenicity locus (PaLoc) and in the putative promoter region of several genes involved in housekeeping, sporulation and antibiotic resistance.

Conclusions: Results presented here suggest that in C. difficile LexA is not merely a regulator of the DNA damage response genes but also controls the expression of dozen genes involved in various other biological functions. Our in vitro results indicate that in C. difficile inactivation of LexA repressor depends on repressor's dissociation from the operators. We report that the repressor's dissociation rates from operators differentiate, thus the determined LexA-DNA dissociation constants imply on the timing of SOS gene expression in C. difficile.

Keywords: Clostridium difficile, Antibiotic resistance, Toxin regulation, SOS system, Surface plasmon resonance, LexA repressor

\section{Background}

Organisms have evolved gene regulatory systems to maintain their genetic integrity. The SOS regulatory network is a paradigm for bacterial response to DNA damage which is controlled by a global transcriptional repressor LexA and an inducer, the recombinase protein RecA. During normal bacterial growth, LexA binds to DNA recognition sequences (operator) positioned near or overlapping the promoter elements of the SOS genes and occludes RNA polymerase, preventing SOS gene transcription. Upon DNA damage, RecA polymerizes on single-stranded DNA (ssDNA) formed at sites of DNA damage, becomes

\footnotetext{
*Correspondence: Matej.Butala@bf.uni-lj.si

'Deceased

${ }^{4}$ Biotechnical Faculty, University of Ljubljana, Department of Biology,

Ljubljana, Slovenia

Full list of author information is available at the end of the article
}

activated $\left(\operatorname{Rec}^{*}\right)$ and facilitates self-cleavage of LexA resulting in coordinated expression of SOS genes [1].

The SOS system was found in almost all eubacterial groups [2]. It was suggested that the LexA operator spread from Gram positive bacteria into Gram negative bacteria, which indicates on the evolutionary origin of the LexA protein [3]. In Escherichia coli, the consensus operator sequence (SOS box) has been identified as $5^{\prime}$ -

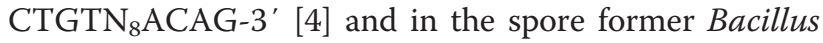
subtilis $5^{\prime}$-GAACN ${ }_{4} \mathrm{GTTC}^{-3}$ ' [5]. The SOS response comprises a variety of physiological processes, not solely involved in the upkeep of the bacterial genome. LexA represses synthesis of toxins [6,7] and antibiotic resistance determinants [8], controls integron cassette recombination [9] and lateral transfer of virulence factor genes [10], as well as drug resistance genes [11]. 
Genes under the control of LexA differ significantly among species. B. subtilis LexA controls a regulon of over 60 genes [12] with only eight of these genes having orthologs in E. coli. Those genes play roles in SOS regulation and excision, recombinational and error-prone DNA repair [5].

C. difficile is a human pathogen causing a spectrum of intestinal diseases ranging from mild diarrhoea associated with antibiotic treatment to, in more severe cases, pseudomembraneous colitis [13]. Despite extensive research focused on the bacterium, knowledge regarding its SOS system is scarce [14]. Among other clostridia species, binding sites for LexA were identified in C. acetobutylicum and C. perfringens and resemble Bacillus LexA operator sequences $[15,16]$. As a suitable target site for LexA is sufficient for binding in vivo [4], we used a robust in silico approach [17] and predicted the LexA-regulated genes of several $C$. difficile strains. In addition, surface plasmon resonance (SPR) was used to confirm the interactions of LexA with regions defined in in silico experiments.

\section{Results and discussion}

\section{Variability of the lexA gene in C. difficile}

C. difficile has been described as a bacterium with highly mosaic genetic composition and multiple attempts have been made to distinguish between various strains and to correlate them with virulence [18]. We first analysed the variability of the repressor LexA encoding gene sequence among various $C$. difficile ribotypes (groups characterized by differences in intergenic regions of RNA operon and used worldwide for $C$. difficile typing) and toxinotypes (characterized by differences in toxin A and B coding region inside the pathogenicity locus called PaLoc) (Additional file 1: Table S1) [19]. Analysis revealed 17 single nucleotide polymorphisms (SNPs) in the lexA gene of $63 C$. difficile sequences among which four SNPs resulted in missense mutations but none of the mutations modified amino acids in the cleavage or active sites of LexA (Figure 1). Our analysis grouped the investigated strains into three clusters according to the $C$. difficile LexA (Figure 2). Cluster I encompassed 3 non-toxinogenic strains and strains of toxinotype 0; Cluster II encompassed strains of toxinotypes III, VIII, IX, and X and finally, Cluster III with the highest number of SNPs, was mostly composed of toxinotype $\mathrm{V}$ strains. Ribotypes for the above stated toxinotypes can be found in the Additional file 1: Table S1. Previous results showed that strains belonging to the epidemic ribotype 027 form a genome wide clade $[20,21]$, typically characterised as the toxinotype III (North American pulsed field gel electrophoresis type 1 - NAP1, REA group BI). Interestingly, ribotypes 016, 019, 036, 075, $111,122,153,156,176,208$ and 273 are closely related to ribotype 027 by comparative genomics [20,21], and those ribotypes were found to encompass the lexA cluster II.
Comparative phylogenomics along with MLST (multilocus sequence typing) and whole genome sequecing has shown that ribotype 078 lineage is different than other $C$. difficile lineages [22]. Moreover PCR ribotype 078 forms a phylogenetically coherent group with ribotypes 033, 045, 066, 078, 126 and 127 [23] - which encompasses lexA cluster III. Genetically distinct strains that belong to ribotypes $078(\mathrm{~V})$ and $126(\mathrm{~V})$ clustered together showing the highest number of SNPs in the lexA gene. The phylogenetic tree based on LexA variability reflects similarities to genetic lineages based on ribotype patterns and comparative genomics analysis.

\section{In silico screening for the LexA-regulated genes in C. difficile} To obtain insight into the LexA regulon genes, we performed in silico genome-wide prediction of LexA binding sites within promoter regions of $C$. difficile. Using the xFiToM software [24], we screened genomes of thirty $C$. difficile strains (Additional file 1: Table S1) for the $C$. acetobutylicum and $C$. perfringens consensus operator sequence of LexA $[15,16]$, allowing for two mismatches in one of the two half sites positioned within $350 \mathrm{bp}$ upstream to $35 \mathrm{bp}$ downstream of a protein coding sequence. Among the thirty genomes, the search yielded at least one putative operator sequence upstream of more than 30 genes involved in a variety of biological processes e.g. DNA repair, transport, virulence and antibiotic resistance (Table 1).

Subsequently, we purified $C$. difficile LexA and RecA proteins with an $\mathrm{N}$-terminal hexa-histidine tag (Additional file 2: Figure S1) as described for E. coli orthologs [25]. SPR analysis was performed to validate the in silico data and determine the LexA-operator interactions in vitro in real time. Most of the interaction sites were found in putative promoter regions of "common" putative SOS genes for the majority of the genomes tested and of putative LexA regulon genes encoding unusual SOS proteins. Out of 20 DNA fragments tested, the repressor interacted with 16 targets (Figure 3A, Additional file 3: Table S2). We determined interaction with operators in promoter regions of the core SOS response genes: $\operatorname{rec} A$, $\operatorname{lex} A$, the genes of the $u v r B A$ operon encoding for components of the UvrABC endonuclease catalyzing nucleotide excision repair and the $\operatorname{ruv} C A$ operon genes, encoding the nuclease that resolves Holliday junction intermediates in genetic recombination. In addition, LexA interacts with putative promoter regions of genes involved in sporulation $(s s p B)$, regulation of DnaA-dependent initiation of DNA replication (soj), several ABC transporters (potC, oppC, MicroScope:CDR20291_2297) and for homologue of a two-component system regulator of the vancomycin resistance cluster $(v a n R)$. The LexA repressor was also found to interact within PaLoc with operator identified 525 base pairs upstream of the toxin A gene $(t c d A)$. 


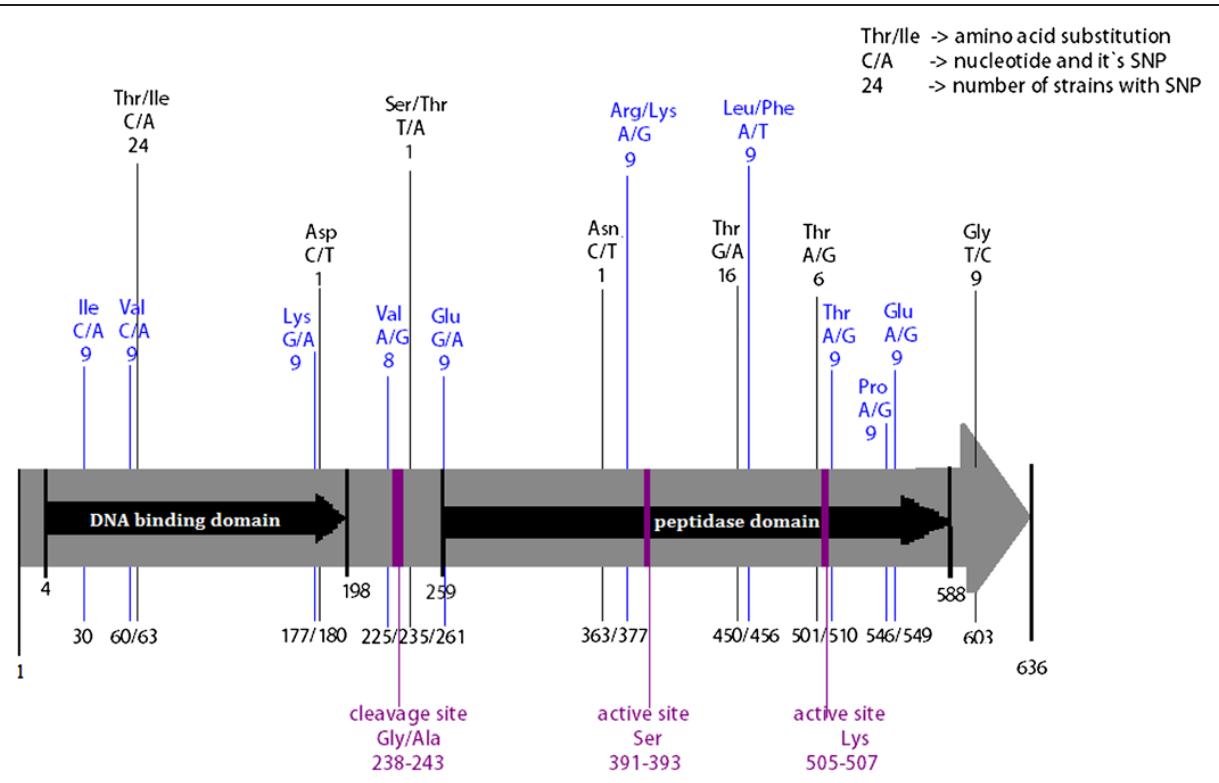

Figure 1 Variability of lexA gene in Clostridium difficile. Representation of the C. difficile 630 strain lexA nucleotide sequence in comparison to repressor sequences of 62 other strains. Grey arrow denotes the nucleotide sequence of the CD630 lexA gene. Black arrows mark the position of domains in LexA. The number of strains with specific SNP and the corresponding nucleotide/aminoacid change is marked above the arrow. The ordinal number of nucleotides in lexA is presented below the arrow. The SNPs marked in blue encompass strains from cluster III, composed mainly of strains belonging to the toxinotype $\mathrm{V}$. The position of the cleavage site and the catalytic residues is marked in purple.

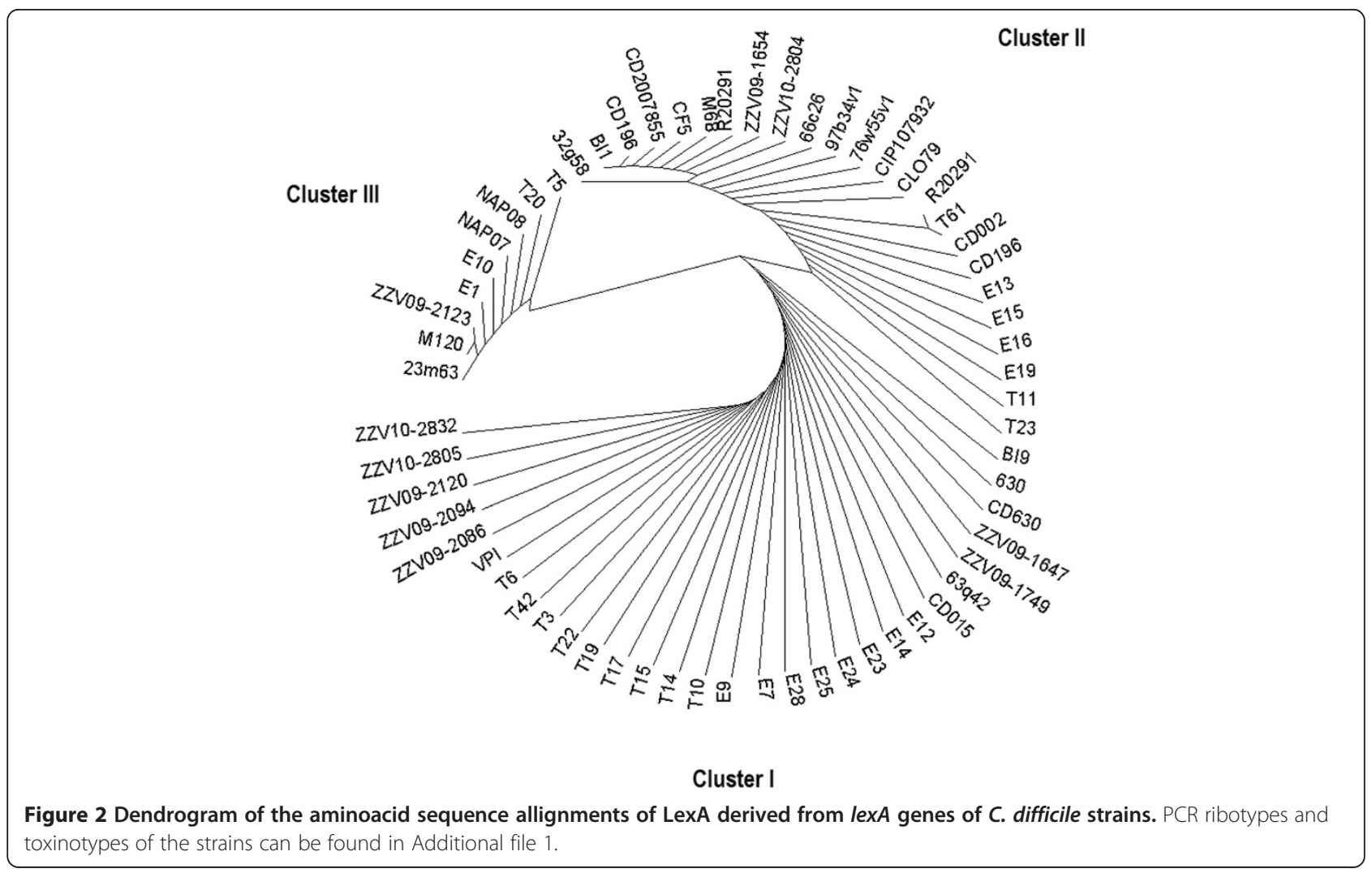


Table 1 In silico predicted LexA binding sites in C. difficile ribotypes

\begin{tabular}{|c|c|c|c|c|c|c|c|c|c|c|c|c|c|c|c|c|c|}
\hline \multirow[b]{3}{*}{$\begin{array}{l}\text { Gene accession } \\
\text { number }\end{array}$} & \multirow[b]{3}{*}{ GENE } & \multirow[b]{3}{*}{ Product } & \multirow[b]{3}{*}{ LeXA BOX } & \multirow[b]{3}{*}{ Distance } & \multicolumn{4}{|c|}{ Various toxinotypes } & \multicolumn{2}{|c|}{ Toxinotype V } & \multicolumn{7}{|c|}{ Toxinotype $0 /$ nontoxinogenic } \\
\hline & & & & & 033 & 027 & 075 & 017 & 078 & 126 & 009 & 001 & 012 & 005 & 087 & 014 & 053 \\
\hline & & & & & 1 strain & 8 strains & 2 strains & 1 strain & 3 strains & 2 strains & 1 strain & 3 strains & 3 strains & 3 strains & 1 strain & 1 strain & 1 strain \\
\hline CDR20291_1854 & lexA & $\begin{array}{l}\text { Transcriptional regulator. } \\
\text { LexA repressor }\end{array}$ & GAAC...GTाT & $-51 /-91$ & 1 & 8 & 2 & 1 & 3 & 2 & 1 & 3 & 3 & 3 & 1 & 1 & 1 \\
\hline CDR20291_1169 & recA & $\begin{array}{l}\text { Protein RecA } \\
\text { (Recombinase A) }\end{array}$ & GAAC....GTा & $-39 /-41$ & 1 & 8 & 2 & 1 & 3 & 2 & 1 & 3 & 3 & 3 & 1 & 1 & 1 \\
\hline CDR20291_2696 & ruvc & $\begin{array}{l}\text { Crossover junction } \\
\text { endodeoxyribonuclease }\end{array}$ & GAAC...GTाT & -65 & 1 & 8 & 2 & 1 & 3 & 2 & 1 & 3 & 3 & 3 & 1 & 1 & 1 \\
\hline CDR20291_3234 & uvrB & $\begin{array}{l}\text { Excinuclease ABC } \\
\text { subunit B }\end{array}$ & GAAC...GTC & -30 & 1 & 8 & 2 & 1 & 3 & 2 & 1 & 3 & 3 & 3 & 1 & 1 & 1 \\
\hline CDR20291_0487 & rusA & $\begin{array}{l}\text { Putative RusA-like } \\
\text { endodeoxyribonuclease }\end{array}$ & GAAC...GTा & -122 & 1 & 4 & 1 & 1 & 3 & 2 & NO & NO & 1 & NO & NO & 1 & NO \\
\hline CDR20291_2024 & $\operatorname{trx} B$ & Thioredoxin reductase & GAAC...GTा & -216 & NO & NO & NO & NO & NO & NO & 1 & NO & NO & NO & NO & NO & NO \\
\hline 63q42v1_580022 & $r p s 3$ & $\begin{array}{l}\text { Putative } 30 \text { S ribosomal } \\
\text { protein S3 }\end{array}$ & GAAC ...GTTA & -284 & NG & NG & 1 & NG & NG & NG & NG & 1 & NG & NG & NG & NO & NO \\
\hline CDR20291_3107 & $s s p B$ & $\begin{array}{l}\text { Small. acid-soluble spore } \\
\text { protein beta }\end{array}$ & GAAC ...GTC & 34 & 1 & 8 & 2 & 1 & 3 & 2 & 1 & 3 & 3 & 3 & 1 & 1 & 1 \\
\hline CDR20291_0784 & oppC & $\begin{array}{l}\text { ABC-type transport } \\
\text { system. oligopeptide }\end{array}$ & GAAC ..GTT & $-285 /-286$ & 1 & 8 & 2 & 1 & 3 & 2 & 1 & 3 & 3 & 3 & 1 & 1 & 1 \\
\hline CDR20291_3532 & soj & $\begin{array}{l}\text { Small walker A ATPase, } \\
\text { chromosome replication }\end{array}$ & GAAC...GTT & -226 & NO & 8 & 2 & 1 & NO & NO & 1 & 3 & 3 & 3 & NO & 1 & 1 \\
\hline CDR20291_2297 & & $\begin{array}{l}\text { Putative multidrug efflux } \\
\text { pump }\end{array}$ & GAAC ..TाT & -138 & 1 & 8 & 2 & 1 & 3 & 2 & 1 & 3 & 3 & 3 & 1 & 1 & 1 \\
\hline 63q42v1_310170 & & ABC-type multidrug-family & GAAC....CTाT & -154 & 1 & 8 & 2 & 1 & 3 & 2 & 1 & 3 & 3 & 3 & 1 & 1 & 1 \\
\hline CDR20291_3125 & $\operatorname{vanR}$ & Regulatory protein vanR & GAAC....ATT & -222 & NO & 8 & 2 & NO & NO & NO & NO & NO & NO & NO & NO & NO & NO \\
\hline CDR20291_0083 & $r p / R$ & 50S ribosomal protein L18 & GAAC...GTTा & $-261 /-262$ & 1 & 8 & 2 & 1 & 3 & 2 & 1 & 3 & 3 & 3 & 1 & 1 & 1 \\
\hline CDR20291_0060 & $r p o B$ & $\begin{array}{l}\text { DNA-directed RNA } \\
\text { polymerase subunit } \beta\end{array}$ & GAAC ..GTT & $-42 /-43$ & 1 & 8 & 2 & 1 & 3 & 2 & 1 & 3 & 3 & 3 & 1 & 1 & 1 \\
\hline CDR20291_1619 & & $\begin{array}{l}\text { Putative transcriptional } \\
\text { regulator }\end{array}$ & GAAC ..GTT & $30 / 31$ & 1 & 8 & 2 & 1 & 3 & 2 & 1 & 3 & 3 & 3 & 1 & 1 & 1 \\
\hline 63q42v1_570034 & & $\begin{array}{l}\text { Helix-turn-helix domain } \\
\text { protein }\end{array}$ & GAAC ...CTा & -97 & NG & 3 & NG & 1 & NG & NG & NG & 1 & NG & 1 & NG & NG & NG \\
\hline CDR20291_0882 & potC & ABC-type transport system. & GAAC ...GTTC & -207 & 1 & 8 & 2 & 1 & 3 & 2 & 1 & 3 & 3 & 3 & 1 & 1 & 1 \\
\hline CDR20291_0584 & $\operatorname{tcd} A$ & Toxin A & GAAC...GTT & -525 & NG & 8 & 2 & NG & 3 & 2 & NG & 3 & 3 & 3 & 1 & 1 & 1 \\
\hline CDR20291_3466 & & Putative cell wall hydrolase & GAAC ..GTT & -68 & NO & 8 & NG & NO & NO & NO & NO & NO & NO & NO & NO & NO & NO \\
\hline CDR20291_2689 & & $\begin{array}{l}\text { Putative membrane } \\
\text { protein }\end{array}$ & GAAC...GTT & -111 & NO & 7 & 2 & 1 & NO & NO & 1 & 3 & 3 & 3 & 1 & 1 & 1 \\
\hline CDR20291_1611 & moaB & $\begin{array}{l}\text { Molybdenum cofactor } \\
\text { biosynthesis }\end{array}$ & GAAC ..GTT & -6 & NO & 8 & 2 & NO & NO & NO & 1 & 3 & NO & 3 & 1 & 1 & NO \\
\hline CDR20291_2775 & celG & $\begin{array}{l}\text { Cellobiose-phosphate } \\
\text { degrading protein }\end{array}$ & GAAC...GTT & -314 & NO & 8 & 2 & NO & NO & NO & NO & NO & NO & NO & NO & NO & NO \\
\hline
\end{tabular}


Table 1 In silico predicted LexA binding sites in C. difficile ribotypes (Continued)

\begin{tabular}{|c|c|c|c|c|c|c|c|c|c|c|c|c|c|c|c|c|c|}
\hline CDR20291_3372 & phnH & $\begin{array}{l}\text { Phosphonate } \\
\text { metabolism protein }\end{array}$ & GAAC...CTIT & -34 & NG & 8 & 2 & 1 & NG & NG & 1 & 3 & 3 & 3 & 1 & 1 & 1 \\
\hline CDR20291_1600 & thic & $\begin{array}{l}\text { Thiamine biosynthesis } \\
\text { protein Thic }\end{array}$ & GAAC...ATT & -175 & 1 & NO & NO & NO & 3 & 2 & NO & NO & NO & NO & NO & NO & NO \\
\hline CDR20291_1940 & & $\begin{array}{l}\text { N-carbamoyl-L-amino } \\
\text { acid hydrolase }\end{array}$ & GAAC...GTाT & -147 & NO & NO & NO & NO & NO & NO & NO & 3 & 3 & NO & NO & NO & 1 \\
\hline CDR20291_2056 & & $\begin{array}{l}\text { Endonuclease/ } \\
\text { exonuclease/ } \\
\text { phosphatase }\end{array}$ & GAAC...GTT & -466 & 1 & 8 & 2 & 1 & 3 & 2 & 1 & 3 & 3 & 3 & 1 & 1 & 1 \\
\hline NAP07v1_640016 & & $\begin{array}{l}\text { Two-component } \\
\text { sensor histidine kinase }\end{array}$ & GAAC...GTT & -217 & NO & 8 & NO & NO & NO & NO & NO & NO & NO & NO & NO & NO & NO \\
\hline CDR20291_0331 & $c b i Q$ & Cobalt transport protein & GAAC...GTT & -122 & 1 & 8 & 2 & 1 & 3 & 2 & 1 & 3 & 3 & 3 & 1 & 1 & 1 \\
\hline CDR20291_2597 & & Putative oxidoreductase & GAAC...CTC & 2 & 1 & 8 & 2 & 1 & 3 & 2 & 1 & 3 & 3 & 3 & 1 & 1 & 1 \\
\hline NAP07v1_470051 & aroF & $\begin{array}{l}\text { P-2-dehydro-3- } \\
\text { deoxyheptonate aldolase }\end{array}$ & GAAC...CTाT & -225 & 1 & NO & NO & NO & 3 & 2 & NO & NO & NO & NO & NO & NO & NO \\
\hline 97b34v1_600001 & & Transposase & GAAC...GTT & -217 & NO & 8 & NO & NO & NO & NO & NO & NO & NO & NO & NO & NO & NO \\
\hline CDE15V2_1270013 & & Putative $\mathrm{cl}$ repressor & GAAC...GTTC & -67 & NG & NG & NG & NG & NG & NG & NG & NG & NG & NO & 1 & NO & NG \\
\hline 63q42v1_370450 & & $\begin{array}{l}\text { Extrachromosomal } \\
\text { origin protein }\end{array}$ & GAAC ..GTाT & 10 & NG & NG & NG & NG & NG & NG & 1 & 3 & 3 & 3 & 1 & 1 & 1 \\
\hline CDR20291_1803 & vexP & $\begin{array}{l}\text { ABC transporter. ATP- } \\
\text { binding/permease }\end{array}$ & GTC....TाT & -85 & NO & 8 & 2 & 1 & NO & NO & NO & 1 & 2 & NO & NO & NO & 1 \\
\hline 97b34v1_250108 & & $\begin{array}{l}\text { ABC-type transport } \\
\text { system. sugar-family }\end{array}$ & GAAC ...GTTC & -267 & NG & 8 & 2 & NG & NG & NG & NG & NG & NG & NG & NG & NG & NG \\
\hline
\end{tabular}

Sequences of putative LexA operators and their positions (according to the start of the gene coding region). Numbers denote strains with the operator identified. NO marks the gene that was identified in the strain but a target LexA site was not found in its promoter region, NG marks that gene was not found in the genome of the strain. 


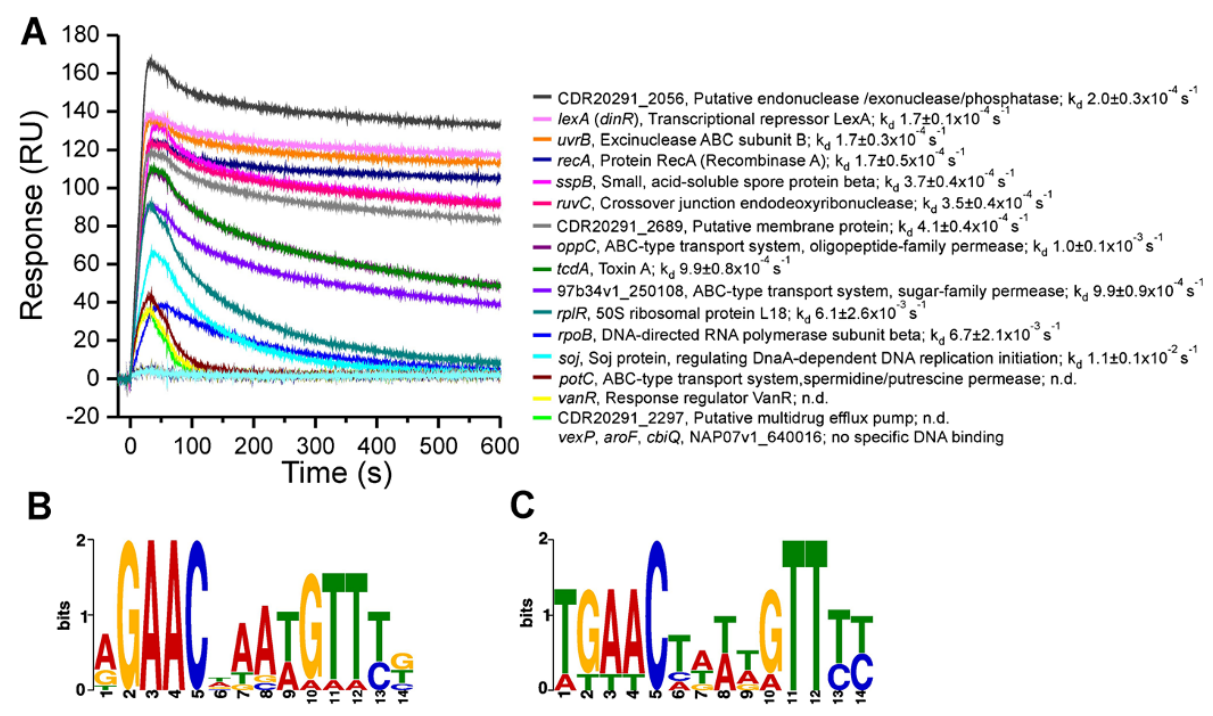

Figure 3 C. difficile LexA regulon genes. (A) SPR sensorgrams of the binding of $C$. difficile LexA with in silico predicted target DNA sites. Selection of LexA target genes determined by in silico and analysed by SPR. LexA ( $20 \mathrm{nM}$ ) was injected for $60 \mathrm{~s}$ across the chip-immobilized DNA fragments containing either of the putative operators and dissociation was followed for $540 \mathrm{~s}$. The representative sensorgrams are shown and the dissociation constants presented as average values of triplicate experiments presented with standard deviation. By n.d. we mark if dissociation rate constant was not determined and the response units are marked by RU. With the MEME tool determined motifs for the target DNA sites found in promoter regions of the genes higher affinity CDR20291_2056, lexA, uvrB, recA, sspB, ruvC, CDR20291_2689, oppC, tcdA, 97b34v1_250108, showing high affinity for LexA (B) or of the genes rplR, rpoB, soj, potC, vanR, CDR20291_2297 to which LexA does not bind stably (C).

While the regulation of toxin production in C. difficile is controlled in response to several environmental signals mediated by pleiotropic regulators (CcpA, CodY, SigD and SigH [26]), the possible regulation through the SOS system sheds new light on this issue. Furthermore, the subinhibitory concentration of SOS-inducing antibiotic ciprofloxacin was recently shown to increase the Toxin A gene expression in C. difficile [27]. Our SPR analysis revealed that also housekeeping genes required for ribosome function $(r p l R)$ and $\beta$ subunit RNA polymerase $(r p o B)$ belong to the LexA regulon, a feature of the SOS network not yet observed in bacteria. Thus, blockage of LexA self-cleavage could impede pivotal functions in C. difficile and this might provide a new approach to treat $C$. difficile infections. Moreover, although putative SOS genes are present in most of the analysed genomes, several of these genes encoding for putative cell wall hydrolase, transposase and for two component sensor histidine kinase seem to be regulated by LexA only in the 027 ribotype strains (Table 1). The in silico analysis showed operators in front of several genes upregulated exclusively in ribotype 075 and 027 (celG, vanR, ABC-type transport system). Furthermore, among the analysed genomes, exclusively in the closely related ribotypes 078, 126 and 033, the LexA target site was not found in front of the soj (regulation of DNA replication) and the phnH (phosphonate metabolism protein). Thus the mode of SOS regulation might be related to phylogenetic lineages.

\section{Cross-reaction of SOS system components in E. coli and C. difficile}

Induction of SOS gene expression is synchronized and the level, timing and duration of expression of the individual LexA regulon genes differs significantly (1). In E. coli, LexA bound to target DNA cannot interact with

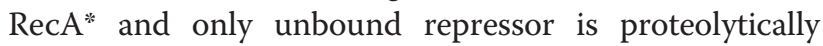
inactivated [25]. Thus the rate of LexA dissociation from operators controls the precise timing of SOS gene expression following induction. Consequently genes with lower affinity LexA target sites are expressed prior to genes with high affinity operators $[1,5]$. To follow up on these results, we used SPR to study interaction of the chip-immobilized $C$. difficile RecA* with LexA interacting with either specific or non-specific DNA. We showed that as in E. coli, the C. difficile LexA repressor interaction with RecA* is prevented by binding to specific DNA targets (Figure 4). In addition, we showed that the key SOS players of $E$. coli and $C$. difficile can cross-react in vitro (Figure 4). Hence, our data indicated that the mode of regulation of the $C$. difficile SOS response resembles the one described for E. coli. Nevertheless, in contrast to the $E$. coli SOS system, we observed among the investigated C. difficile genes, a slowest LexA dissociation from operators of the core SOS genes, $r e c A$, lexA and $u v r B$ (Figure 3A and $\mathrm{B}$, Table 2), implying that these are the last genes upregulated upon SOS induction. For instance, LexA dissociation from the E. coli recA operator is more than 20-times faster than from $C$. difficile with regard to the dissociation 


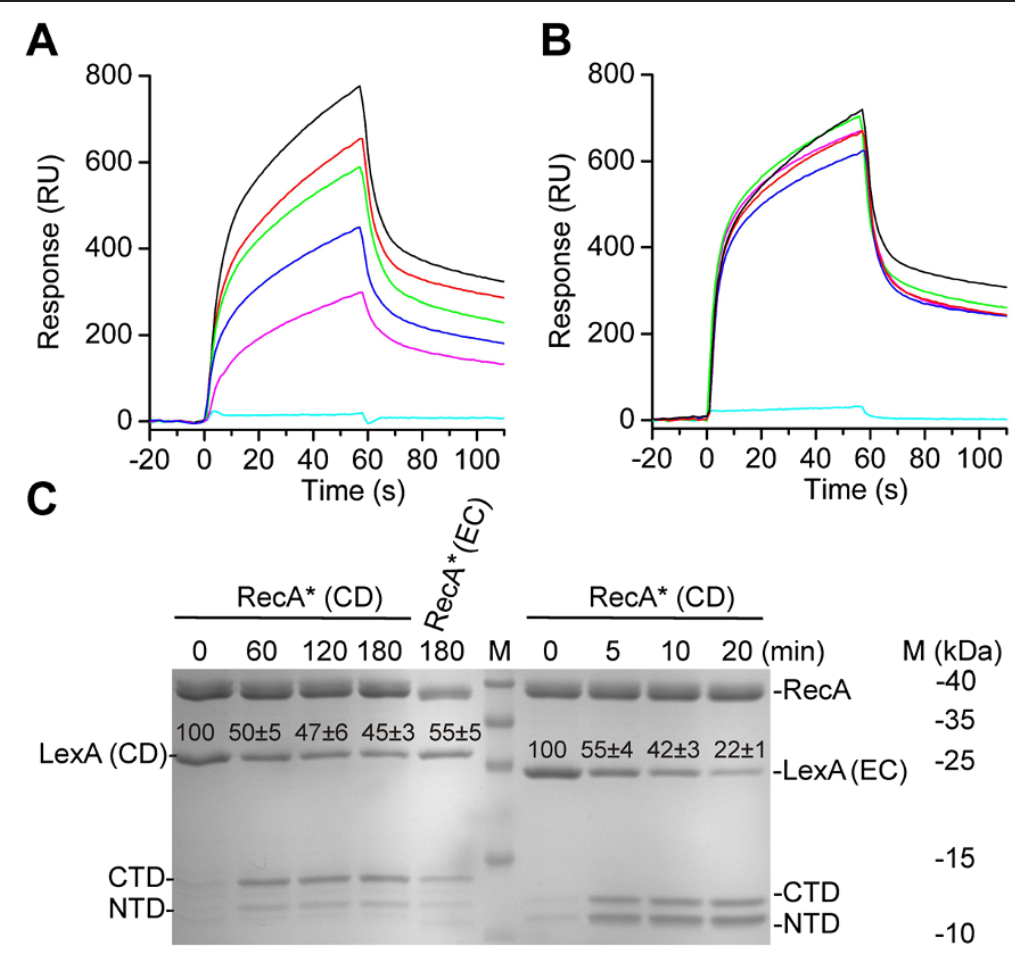

Figure 4 Specific DNA precludes $C$. difficile RecA*-LexA interaction. Interaction of C. difficile LexA repressor $(2.6 \mu M)$ incubated with specific, 22-bp recA operator (A) or with non-specific DNA fragment, recA operator with modified six nucleotides (B), with the chip-immobilized C. difficile $\operatorname{Rec}^{*}$ ( 2000 response units). The used DNA interacting with repressor was in $1.4 \mu \mathrm{M}$ (black line), $2.7 \mu \mathrm{M}$ (red line), $4.0 \mu \mathrm{M}$ (green line), $5.4 \mu \mathrm{M}$ (blue line), $8.1 \mu \mathrm{M}$ (pink line) concentration. The cyan line presents sensorgram of the free DNA at $8.1 \mu \mathrm{M}$ concentration interacting with the RecA*. (C) In vitro repressor cleavage pattern exhibits that purified E. coli and C. difficile key SOS players can cross-react. C. difficile proteins are marked as RecA* $(C D)$, LexA (CD) and E. coli proteins as RecA* $(E C)$ and LexA (EC), respectively. Time course (min) of either C. difficile or E. coli RecA*-induced inactivation of LexA (CD) or LexA (EC) repressor. Quantification of LexA is presented on the gel above the respective band as the ratio (\%) of the protein density value of the initial sample $(0 \mathrm{~min})$ relative to the density value obtained from the proteins after indicated time points after addition of RecA*, shown with standard deviation.

constants of $4.8 \pm 2.1 \times 10^{-3} \mathrm{~s}^{-1}(21)$ and $1.7 \pm 0.5 \times 10^{-4}$ $\mathrm{s}^{-1}$, respectively.

We propose that in C. difficile, strong repression of core SOS genes affects the magnitude of the system 's induction. Thus, the low association and non-stable LexA binding to putative regulatory regions of genes encoding the RNA polymerase $\beta$ subunit $(r p o B), 50 \mathrm{~S}$ ribosomal protein $(r p l R)$, spermidine/putrescine permease (potC), vancomycin response regulator $(\mathrm{vanR})$ and putative multidrug-efflux-pump [MicroScope: CDR20291_2297], indicates that LexA contributes to fine-tuning of expression of these genes independently of substantial $r e c A$ induction (Figure 3).

The paradigm of the SOS system is that DNA repair genes are rapidly induced in the SOS response to deal with DNA lesions $[1,2,28]$. However, comparison of induction of LexA regulon genes in B. subtilis and E. coli in response to double-strand breaks reveals diversity [29]. After DNA damage, the velocity of assembly of

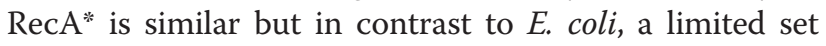
of LexA-regulated genes are induced early in the response in B. subtilis. Our in vitro results suggest that also in $C$. difficile, induction of the LexA-regulated DNA repair genes might be induced later in the SOS response as the core SOS gene promoter regions harbour high affinity LexA targets. According to the differences in LexA-operator affinities we predict that upon DNA damage, various biological processes will be derepressed without induction of the SOS DNA repair.

\section{Conclusions}

We have generated maps of LexA target sites within the genomes of $C$. difficile strains. We predict that SOS functions in $C$. difficile are not solely involved in the DNA repair but are probably linked to other biological functions (virulence factors, sporulation,...). As C. difficile infection is a growing problem in healthcare facilities and community patients, further characterisation of the LexA-regulon could provide key insights into pathogenesis. Our data suggest that molecules targeting key SOS proteins could block several houskeeping functions and could provide next generation of $C$. difficile antibiotics. Furthermore, the defined differences in lexA gene group C. difficile strains into three clusters which correlated 
Table 2 Target DNA sequences of the putative SOS genes of the R20291 strain used for the SPR analysis

\begin{tabular}{|c|c|c|c|c|}
\hline GENE & Function & Product & $\begin{array}{l}\text { Putative LexA operator (R20291 strain) } \\
\left(5^{`}--3^{\prime}\right)\end{array}$ & $\begin{array}{l}\text { Distance from } \\
\text { CDS }\end{array}$ \\
\hline lexA & SOS response & $\begin{array}{l}\text { Transcriptional regulator. LexA } \\
\text { repressor }\end{array}$ & AGGAACAAATGTTTGC & $-51 /-91$ \\
\hline recA & $\begin{array}{l}\text { SOS response/DNA } \\
\text { repair }\end{array}$ & Protein RecA (Recombinase A) & GAGAACAAATGTTTGT & $-39 /-41$ \\
\hline ruvC & DNA repair & $\begin{array}{l}\text { Crossover junction } \\
\text { endodeoxyribonuclease }\end{array}$ & TAGAACATAAGTTTIT & -65 \\
\hline$u v r B$ & DNA repair & Excinuclease $A B C$ subunit $B$ & AGGAACTAATGTTCGA & -30 \\
\hline $\operatorname{ssp} B$ & Spores & Small. acid-soluble spore protein beta & CAGAACAGTAGTTCCA & 34 \\
\hline oppC & Spores/ABC transporter & $\begin{array}{l}\text { ABC-type transport system. } \\
\text { oligopeptide-family }\end{array}$ & TAGAACATAAAAATTT & $-285 /-286$ \\
\hline soj & $\begin{array}{l}\text { Regulation of DNA } \\
\text { replication }\end{array}$ & protein Soj & TTGAACTTTAGTTTCT & -226 \\
\hline CDR20291_2297 & Antibiotics & Putative multidrug efflux pump & AAGAACATCTGAAAAG & -138 \\
\hline van $R$ & Antibiotics & Response regulator VanR & CAGAACTATTATTTTA & -222 \\
\hline$r p / R$ & DNA/RNA & $50 S$ ribosomal protein $\mathrm{L} 18$ & ATGAACTTAGGTTTCT & $-261 /-262$ \\
\hline rpoB & DNA/RNA & $\begin{array}{l}\text { DNA-directed RNA polymerase subunit } \\
\text { beta }\end{array}$ & ATGAACTATTGTTTTA & $-42 /-43$ \\
\hline potC & Biofilm & $\begin{array}{l}\text { ABC-type transport system. spermidine/ } \\
\text { putrescine }\end{array}$ & TGGAACTITGGTTCAG & -207 \\
\hline$t c d A$ & Toxicity & Toxin A & GTGAACCAATGTTTGA & -525 \\
\hline CDR20291_2689 & Cell wall/membrane & Putative membrane protein & TGGAACTITAGTTCTA & -111 \\
\hline CDR20291_2056 & Signalling & $\begin{array}{l}\text { Putative endonuclease/exonuclease/ } \\
\text { phosphatase }\end{array}$ & AAAAACACCCGTTCTGCAAACATTCGTTCTG & -466 \\
\hline NAP07v1_640016 & Signalling/Chemotaxis & $\begin{array}{l}\text { Two-component sensor histidine } \\
\text { kinase }\end{array}$ & GAGAACCTGTGTTTIT & -217 \\
\hline$c b i Q$ & Transport & Cobalt transport protein & ATGAACCATGGTTTAG & -122 \\
\hline aroF & Transport & $\begin{array}{l}\text { Phospho-2-dehydro-3-deoxyheptonate } \\
\text { aldolase }\end{array}$ & ATGAACTATTCTTTCT & -225 \\
\hline vexP & $\mathrm{ABC}$ transporter & $\begin{array}{l}\text { ABC transporter. ATP-binding/permease } \\
\text { protein }\end{array}$ & AAGTTCAAATTTTTGA & -85 \\
\hline 97b34v1_250108 & $\mathrm{ABC}$ transporter & ABC-type transport system sugar-family & AAGAACTAAAGTTCCT & -267 \\
\hline
\end{tabular}

well with phylogentic lineages suggested by comparative genomic approaches.

\section{Materials and Methods}

\section{Source}

The $C$. difficile genomes were obtained from an opened access NCBI database [30] and an undisclosed access to MicroScope platform [31]. The strains used for amplification with PCR and sequencing belong to the strain collection of the Institute of Public Health Maribor. The list of strains used for analysis of the LexA variability and regulon is presented in the Additional file 1: Table S1.

\section{Variability of lexA gene}

Variability of lexA in $C$. difficile was compared by analysis of alignment and phylogenetic trees of nucleotides and amino acid sequences performed with Vector NTI
(Invitrogen) and with the interactive viewer for phylogenetic trees: Dendroscope [32]. Sixty three sequences were analysed in total (NCBI - 9 strains, MicroScope 44 strains, PCR product of in-house strains - 10). Strains CD196, R20291 and 630 were obtained from both databases. List of strains used for $\operatorname{lex} A$ gene variability can be found in Additional file 1: Table S1.

\section{In silico determination of the $C$. difficile SOS regulon}

The search for LexA binding sites was performed for 30 genomes (Additional file 1: Table S1). The number of strains covering ribotypes was as follows: ribotype $027-$ eight strains; ribotypes: 078, 001, 005 and 012 - three strains from each; ribotypes 075 and 126 two strains from each and one genome from each ribotypes 017, 087, 014, 053. The analysis was performed with xFiToM software [24]. The searched motifs, based on C. acetobutylicum 
and $C$. perfringens consensus, were as follows: GAAC nnnnGTTT, GAACnnnnGTTC, GAACnnnnnTTT, GA ACnnnnnTTC. The default options were used with the limitation to 350 base pairs upstream to 35 bp downstream of a protein coding sequence. An exception was the promoter region of the putative endonuclease/exonuclease/ phosphatase (MicroScope: CDR20291_2056) where we found 2 operators positioned approximately 460 upstream of the coding sequence and hence, we included the targets in the analysis. The results were subjected to manual check by extraction of gene sequences along with 1000 base pairs upstream and downstream followed by alignment and research of the binding sites.

\section{Cloning, expression and isolation of recombinant $C$. difficile LexA and RecA protein}

The $C$. difficile 630 chromosomal DNA was extracted by the Genomic DNA purification kit (Thermo Scientific) according to the manufacturer's instructions. The $\operatorname{lex} A$ and $r e c A$ genes were amplified by PCR from the chromosomal DNA using specific primers (DinR_U 5' -GCGCGGATCC AGTGATGTTATGTATTTAGATC-3' - DinR_D 5' -CGC ACGCGTCTATTTAATAACTCTAAATAC-3') and (Rec A_U 5'-GCGCGGATCCAGTGTAGATCAAGAAAAAT TAAAAG-3' - RecA_D 5'-CGCACGCGTTTATTCTTC TACAATTTCTTTTG-3'), respectively. The PCR products were then purified and cut with BamHI and MluI and cloned into pET8c vector digested by the same enzyme to create plasmids pDinRCD and pRecACD for expression of proteins fusion with $\mathrm{N}$-terminal $\mathrm{His}_{6}$ tag. Large-scale expression of proteins was performed in the E. coli BL21 (DE3) strain and purified from the bacterial cytoplasm by Ni-NTA affinity chromatography as described for the E. coli key SOS proteins [25]. PD10 desalting columns (GE Healthcare) were used for exchange of the buffer. The proteins were stored at $-80^{\circ} \mathrm{C}$ in $20 \mathrm{mM}$ $\mathrm{NaH}_{2}$ PO4 (pH 7.4), $0.2 \mathrm{mM} \mathrm{NaCl}$. Protein concentrations were determined using NanoDrop1000 (Thermo Scientific) and extinction coefficients at $280 \mathrm{~nm}$ of 7450 $\mathrm{M}^{-1} \mathrm{~cm}^{-1}$ for recombinant LexA and $16055 \mathrm{M}^{-1} \mathrm{~cm}^{-1}$ for recombinant RecA.

\section{Surface plasmon resonance assays}

C. difficile LexA-operator measurements were performed on a Biacore T100 (GE Healthcare) at $25^{\circ} \mathrm{C}$ as described [6]. The 3'-biotynilated 5-CGCTCGAGTA GTAAC-TEG-Bio-3'primer was immobilized on the flow cell 2 (Fc2) of the streptavidin sensor chip (GE Healthcare) in SPR buffer containing $20 \mathrm{mM}$ Tris- $\mathrm{HCl}$ (pH 7.4), $140 \mathrm{mM} \mathrm{NaCl}, 0.005 \%$ surfactant P20 (GE Healthcare). To prepare double stranded DNA (dsDNA) fragments with the predicted $C$. difficile LexA operators, complementary pairs of primers presented in Additional file 3: Table S2 were dissolved in $20 \mathrm{mM} \mathrm{NaH}{ }_{2} \mathrm{PO}_{4}$
(pH 7.4), 0.14 M NaCl and mixed in 1:1.5 (mol : mol) ratio for the longer to shorter primer, respectively. Primers were annealed in temperature gradient from $95^{\circ} \mathrm{C}$ to $4^{\circ} \mathrm{C}$ $(\sim 1.5 \mathrm{~h})$ in PCR machine (Eppendorf). So prepared DNA fragments were approximately 22 bp duplex DNAs with 15-nucleotide overhangs complementary to the chip-immobilized primer. Approximately 44 response units of either DNA fragment were hybridised at $2 \mu \mathrm{l} \mathrm{min}{ }^{-1}$ to the $\mathrm{Fc} 2$. The interaction of $C$. difficile LexA with the chip-immobilized DNAs was analysed by injecting repressor in SPR buffer in $20 \mathrm{nM}$ concentration across the chip surface at $100 \mu \mathrm{l} \mathrm{min}^{-1}$ for a minute and dissociation was followed for 9 minutes. The regeneration of the surface was achieved injecting $12 \mathrm{~s}$ pulse of $50 \mathrm{mM} \mathrm{NaOH}$ at $100 \mu \mathrm{l} \mathrm{min}^{-1}$. The experiments were performed in triplicates and the representative sensorgrams are shown. Data were fitted to a 1:1 binding model to obtain the dissociation rates constants. Program MEME was used to determine LexA binding motifs [33].

SPR C. difficile RecA*-LexA interaction measurements were performed on a Biacore X (GE Healthcare) at $25^{\circ} \mathrm{C}$ as described to study the interaction among the key E. coli SOS proteins [25]. Experiments were performed in SPR_2 buffer (20 mM NaH $\mathrm{PO}_{4}(\mathrm{pH} 7.4), 150 \mathrm{mM}$ $\mathrm{NaCl}, 2 \mathrm{mM} \mathrm{MgCl} 2$, $1 \mathrm{mM}$ DTT, $1 \mathrm{mM}$ ATP (Sigma Aldrich), $0.005 \%$ surfactant P20 (GE Healthcare). C. diffcile LexA repressor $(2.6 \mu \mathrm{M})$, interacting with either the 22 bp recA operator DNA fragment or with the $22 \mathrm{bp}$ non-specific DNA fragment derived from the recA operator, was passed over the sensor chip with immobilized RecA* ( 2000 response units). LexA specific DNA (recA operator) or non-specific DNA, with 6 nucleotide changed in comparison to the specific DNA, was prepared by hybridising primers (1:1 mol to mol ratio) $5^{\prime}$-CAAGA GAACAAATGTTTGTAGA-3' and 5' -TCTACAAACA TTTGTTCTCTTG-3' or 5' -CAAGACCGGAAATCCTT GTAGA-3' and 5'-TCTACAAGGATTTCCGGTCTTG-3', respectively. The $\operatorname{RecA}^{*}$-LexA interaction was assayed at $10 \mu \mathrm{l} / \mathrm{min}$ for $60 \mathrm{~s}$ and the dissociation followed for $60 \mathrm{~s}$. The sensor chip was regenerated as described [25].

\section{Repressor cleavage assay}

Activation of either $E$. coli or $C$. difficile RecA $(10 \mu \mathrm{M})$ nucleoprotein filament was performed on ice for $2 \mathrm{~h}$ as described [34]. RecA*-stimulated $(\sim 2 \mu \mathrm{M})$ cleavage of LexA were performed in $20 \mathrm{mM}$ Tris, $\mathrm{pH} 7.4,5 \mathrm{mM}$ $\mathrm{MgCl}_{2}, 1 \mathrm{mM}$ ATP- $\gamma-\mathrm{S}$ (Sigma), and $1 \mathrm{mM}$ DTT as described [25]. Samples were resolved on 12\% SDS PAGE gels in MOPS running buffer (Invitrogen) and stained by Page blue protein stain (Thermo Scientific). The resolved bands were quantified using a G:Box (Syngene). The integrated optical densities of the LexA monomers were determined. The LexA levels throughout the time 
course were compared and are presented as the ratio of the density value for the sample at time indicated as $0 \mathrm{~min}$ relative to the density value obtained from the samples obtained later in the LexA cleavage reaction. The experiments were performed two times and representative gels are shown.

\section{Additional files}

Additional file 1: Table S1. List of genomes used for analysis of SOS regulon and LexA variability. The names of the strains used for SOS regulon analysis are additionally bolded.

Additional file 2: Figure S1. Comassie stained C. difficile (CD) LexA and RecA proteins and the LexA protein from Escherichia coli (EC). Proteins used in the study were more than $95 \%$ pure. Approximately $5 \mu \mathrm{g}$ of each protein was loaded on the SDS-PAGE gel.

Additional file 3: Table S2. Pairs of primers used to construct double stranded DNAs harbouring predicted LexA target sites. Putative LexA operators are underlined.

\section{Competing interests}

The authors declare that they have no competing interests.

\section{Authors' contributions}

$B M W, N P$ and $M B$ designed and performed most of the experiments, VH, NP and GA contributed to SPR experiments, NP and DZB contributed to expression and cleavage experiments; BD and MR contributed toward strain and genome selection. All authors contributed to analysis of the results and during the preparation of the manuscript.

\section{Acknowledgments}

The research leading to these results has received funding from the European Community's Seventh Framework Programme FP7/2007-2013 under grant agreement No. 237942.

Part of this work was supported by grants from the Slovenian Research Agency (Z1-2142 and J4-2111).

\section{Author details}

${ }^{1}$ Institute of Public Health Maribor, Centre for Microbiology, Maribor, Slovenia. ${ }^{2}$ Faculty of Medicine, University of Maribor, Maribor, Slovenia. ${ }^{3}$ Centre of Excellence for Integrated Approaches in Chemistry and Biology of Proteins, Ljubljana, Slovenia. ${ }^{4}$ Biotechnical Faculty, University of Ljubljana, Department of Biology, Ljubljana, Slovenia. ${ }^{5}$ National Institute of Chemistry, Ljubljana, Slovenia. 'Laboratoire Pathogenèse des Bactéries Anaérobies, Département de Microbiologie, Institut Pasteur, Paris, France.

Received: 23 December 2013 Accepted: 27 March 2014 Published: 8 April 2014

\section{References}

1. Courcelle J, Khodursky A, Peter B, Brown PO, Hanawalt PC: Comparative gene expression profiles following UV exposure in wild-type and SOS-deficient Escherichia coli. Genetics 2001, 158:41-64.

2. Erill I, Campoy S, Barbe J: Aeons of distress: an evolutionary perspective on the bacterial SOS response. FEMS Microbiol Rev 2007, 31:637-656.

3. Mazon G, Erill I, Campoy S, Cortes P, Forano E, Barbe J: Reconstruction of the evolutionary history of the LexA-binding sequence. Microbiology 2004, 150:3783-3795.

4. Wade JT, Reppas NB, Church GM, Struhl K: Genomic analysis of LexA binding reveals the permissive nature of the Escherichia coli genome and identifies unconventional target sites. Genes Dev 2005, 19:2619-2630.

5. Au N, Kuester-Schoeck E, Mandava V, Bothwell LE, Canny SP, Chachu K, Colavito SA, Fuller SN, Groban ES, Hensley LA, O'Brien TC, Shah A, Tierney JT, Tomm LL, O'Gara TM, Goranov Al, Grossman AD, Lovett CM: Genetic composition of the Bacillus subtilis SOS system. J Bacteriol 2005, 187:7655-7666.
6. Butala M, Sonjak S, Kamensek S, Hodoscek M, Browning DF, Zgur-Bertok D, Busby SJ: Double locking of an Escherichia coli promoter by two repressors prevents premature colicin expression and cell lysis. Mol Microbiol 2012, 86:129-139.

7. Quinones $\mathrm{M}$, Kimsey HH, Waldor MK: LexA cleavage is required for CTX prophage induction. Mol Cell 2005, 17:291-300.

8. Da Re S, Garnier F, Guerin E, Campoy S, Denis F, Ploy MC: The SOS response promotes qnrB quinolone-resistance determinant expression. EMBO Rep 2009, 10:929-933.

9. Guerin E, Cambray G, Sanchez-Alberola N, Campoy S, Erill I, Da Re S, Gonzalez-Zorn B, Barbe J, Ploy MC, Mazel D: The SOS response controls integron recombination. Science 2009, 324:1034.

10. Ubeda C, Maiques E, Knecht E, Lasa I, Novick RP, Penades JR: Antibiotic-induced SOS response promotes horizontal dissemination of pathogenicity island-encoded virulence factors in staphylococci. Mol Microbiol 2005, 56:836-844.

11. Beaber JW, Hochhut B, Waldor MK: SOS response promotes horizontal dissemination of antibiotic resistance genes. Nature 2004, 427:72-74.

12. Goranov Al, Kuester-Schoeck E, Wang JD, Grossman AD: Characterization of the global transcriptional responses to different types of DNA damage and disruption of replication in Bacillus subtilis. J Bacteriol 2006 , 188:5595-5605.

13. Rupnik M, Wilcox MH, Gerding DN: Clostridium difficile infection: new developments in epidemiology and pathogenesis. Nat Rev Microbiol 2009, 7:526-536.

14. Gebhart D, Williams SR, Bishop-Lilly KA, Govoni GR, Willner KM, Butani A, Sozhamannan S, Martin D, Fortier LC, Scholl D: Novel high-molecular-weight, R-type bacteriocins of Clostridium difficile. J Bacterio/ 2012, 194:6240-6247.

15. Johnston JL, Sloan J, Fyfe JA, Davies JK, Rood Jl: The recA gene from Clostridium perfringens is induced by methyl methanesulphonate and contains an upstream Cheo box. Microbiology 1997, 143(Pt 3):885-890.

16. Nuyts S, Van Mellaert L, Barbe S, Lammertyn E, Theys J, Landuyt W, Bosmans E, Lambin P, Anne J: Insertion or deletion of the Cheo box modifies radiation inducibility of Clostridium promoters. Appl Environ Microbiol 2001, 67:4464-4470.

17. Cornish JP, Matthews F, Thomas JR, Erill I: Inference of self-regulated transcriptional networks by comparative genomics. Evol Bioinform Online 2012, 8:449-461.

18. Walker AS, Eyre DW, Wyllie DH, Dingle KE, Griffiths D, Shine B, Oakley S, O'Connor L, Finney J, Vaughan A, Crook DW, Wilcox MH, Peto TE: Relationship between bacterial strain type, host biomarkers, and mortality in Clostridium difficile infection. Clin Infect Dis 2013, 56:1589-1600.

19. Rupnik M: Heterogeneity of large clostridial toxins: importance of Clostridium difficile toxinotypes. FEMS Microbiol Rev 2008, 32:541-555.

20. Marsden GL, Davis IJ, Wright VJ, Sebaihia M, Kuijper EJ, Minton NP: Array comparative hybridisation reveals a high degree of similarity between UK and European clinical isolates of hypervirulent Clostridium difficile. BMC Genomics 2010, 11:389.

21. Stabler RA, He M, Dawson L, Martin M, Valiente E, Corton C, Lawley TD, Sebaihia M, Quail MA, Rose G, Gerding DN, Gibert M, Popoff MR, Parkhill J, Dougan G, Wren BW: Comparative genome and phenotypic analysis of Clostridium difficile 027 strains provides insight into the evolution of a hypervirulent bacterium. Genome Biol 2009, 10:R102.

22. Stabler RA, Dawson LF, Valiente E, Cairns MD, Martin MJ, Donahue EH, Riley TV, Songer JG, Kuijper EJ, Dingle KE, Wren BW: Macro and micro diversity of Clostridium difficile isolates from diverse sources and geographical locations. PLoS One 2012, 7:e31559.

23. Knetsch CW, Hensgens MP, Harmanus C, van der Bijl MW, Savelkoul PH, Kuijper EJ, Corver J, Van Leeuwen HC: Genetic markers for Clostridium difficile lineages linked to hypervirulence. Microbiology 2011, 157:3113-3123.

24. Erill I, O'Neill MC: A reexamination of information theory-based methods for DNA-binding site identification. BMC Bioinformatics 2009, 10:57.

25. Butala M, Klose D, Hodnik V, Rems A, Podlesek Z, Klare JP, Anderluh G, Busby SJ, Steinhoff HJ, Zgur-Bertok D: Interconversion between bound and free conformations of LexA orchestrates the bacterial SOS response. Nucleic Acids Res 2011, 39:6546-6557.

26. El Meouche I, Peltier J, Monot M, Soutourina O, Pestel-Caron M, Dupuy B, Pons JL: Characterization of the SigD Regulon of C. difficile and Its Positive Control of Toxin Production through the Regulation of tcdR. PLoS One 2013, 8:e83748. 
27. Aldape MJ, Packham AE, Nute DW, Bryant AE, Stevens DL: Effects of ciprofloxacin on the expression and production of exotoxins by Clostridium difficile. J Med Microbiol 2013, 62:741-747.

28. Butala M, Zgur-Bertok D, Busby SJ: The bacterial LexA transcriptional repressor. Cell Mol Life Sci 2009, 66:82-93.

29. Simmons LA, Goranov Al, Kobayashi H, Davies BW, Yuan DS, Grossman AD, Walker GC: Comparison of responses to double-strand breaks between Escherichia coli and Bacillus subtilis reveals different requirements for SOS induction. J Bacteriol 2009, 191:1152-1161.

30. Geer LY, Marchler-Bauer A, Geer RC, Han L, He J, He S, Liu C, Shi W, Bryant SH: The NCBI BioSystems database. Nucleic Acids Res 2010, 38:D492-496.

31. Monot M, Boursaux-Eude C, Thibonnier M, Vallenet D, Moszer I, Medigue C, Martin-Verstraete I, Dupuy B: Reannotation of the genome sequence of Clostridium difficile strain 630. J Med Microbiol 2011, 60:1193-1199.

32. Huson DH, Richter DC, Rausch C, Dezulian T, Franz M, Rupp R. Dendroscope: an interactive viewer for large phylogenetic trees. BMC Bioinformatics 2007, 8:460.

33. Bailey TL, Boden M, Buske FA, Frith M, Grant CE, Clementi L, Ren J, Li WW, Noble WS: MEME SUITE: tools for motif discovery and searching. Nucleic Acids Res 2009, 37:W202-208

34. Giese KC, Michalowski CB, Little JW: RecA-Dependent Cleavage of LexA Dimers. J Mol Biol 2008, 377:148-161.

doi:10.1186/1471-2180-14-88

Cite this article as: Walter et al:: The LexA regulated genes of the Clostridium difficile. BMC Microbiology 2014 14:88.

\section{Submit your next manuscript to BioMed Central and take full advantage of:}

- Convenient online submission

- Thorough peer review

- No space constraints or color figure charges

- Immediate publication on acceptance

- Inclusion in PubMed, CAS, Scopus and Google Scholar

- Research which is freely available for redistribution 